\title{
Позиция
}

ГРИБИН Николай Петрович - доктор юридических наук, профессор Московского государственного института международных отношений (университет) МИД России (119454, Россия, г. Москва, nр-кт Вернадского, 76; n.gordin40@gmail.com)

ПЛЕТНЕВ Валерий Яковлевич - кандидат юридических наук, профессор; консультант Военной академии, г. Москва, полковник в отставке

\section{«БЕЛОРУССКИЙ СИНДРОМ» В КОНТЕКСТЕ ОБНОВЛЕННОЙ ДОРОЖНОЙ КАРТЫ «ЦВЕТНЫХ РЕВОЛЮЦИИ»}

\begin{abstract}
Аннотация. В статье дается анализ политического кризиса в Беларуси после провозглашения победы А.Г. Лукашенко на президентских выборах 9 августа 2020 г. Авторы раскрывают внешние и внутренние причины возникновения протестных выступлений жителей страны, освещают механизм инспирирования и поддержки попытки государственного переворота в республике, высказывают прогнозы развития ситуации.
\end{abstract}

Ключевые слова: «мягкая сила», инструменты «цветных революций», внешние факторы, политтехнологии, информационно-коммуникационные ресурсы, объекты воздействия, протестные акции, антиобщественное поведение, оппозиционные силы, национальная безопасность Российской Федерации

$\mathrm{C}$ ообытия лета-осени 2020 г. в Беларуси в значительной степени изменили представление о ней как о некоем стабильном, бесконфликтном и успешно развивающемся государстве, сумевшем благополучно пройти сложный период трансформации от статуса одной из республик Советского Союза к полной государственной независимости и занять достойное место на постсоветском пространстве. В отличие от ряда других республик, входивших в состав СССР, Белоруссия проделала этот путь практически безболезненно и за короткий период времени сумела вполне уверенно определить вектор своего развития. В значительной степени этому способствовали сохранившийся после развала Советского Союза высокотехнологичный научно-промышленный потенциал, развитое современное сельское хозяйство, а также такой немаловажный национальный фактор, как традиционно трудолюбивый и законопослушный белорусский народ.

Вместе с тем массовые протестные выступления, захлестнувшие Беларусь после обнародования итогов прошедших 9 августа 2020 г. президентских выборов, не могут считаться неким спонтанным, сугубо локальным явлением, и в первую очередь потому, что, помимо ряда причин, связанных с особенностями проводимой властями республики внутренней политики, содержат в себе четко выраженное воздействие внешнего фактора, отражающего сложный комплекс закономерных объективных и субъективных особенностей мирового развития, которые в последние десятилетия вызывают социально-политические потрясения в разных точках планеты.

Для достижения своих геостратегических целей, приобретения и укрепления мировых и региональных торгово-экономических позиций глобальные игроки используют весь имеющийся в их распоряжении арсенал политических, экономических, правовых и дипломатических средств, нередко прибегая в т.ч. и к силовым методам.

Однако все чаще в этом арсенале на передний план выдвигаются альтернативные инструменты «мягкой силы», предназначенные оказывать политическое, экономическое и психологическое воздействие на страны - объекты 
осуществления «цветных революций». Все больший удельный вес в структуре компонентов «мягкой силы» приобретают информационно-коммуникационные ресурсы, которые применяются в качестве орудия политического давления на суверенные государства путем деструктивного информационно-психологического воздействия на широкие слои населения в целях формирования внутренних кризисных процессов, провоцирования общественного недовольства, организации протестной антиправительственной деятельности и массовых беспорядков. Это, в конечном счете, должно привести к замене государственного руководства, неугодного закулисным инициаторам демонтажа власти, прозападно ориентированными марионеточными лидерами.

С позиций интересов национальной безопасности Российской Федерации в этом контексте особую значимость приобретают исследования новейших технологий организации и осуществления оппозиционных выступлений, направленных на подрыв конституционного строя государств-мишеней и якобы ненасильственное изменение их политической системы. В этом ряду наиболее рельефно проявились уже известные атрибуты модели переворотов в Беларуси, на которую многие годы оказывается нарастающее политическое, экономическое, дипломатическое, санкционное и информационное давление коллективного Запада.

В качестве основных задач деструктивного информационно-коммуникационного воздействия выдвигались:

- дискредитация и разрушение традиционных национальных ценностей и идеологических ориентаций, отрицание социально-экономических, технологических и культурных достижений страны, позитивных исторических оценок ее прошлого, опорочивание национальных героев, разжигание недовольства существующим общественным порядком в стране, склонение к протестным акциям, антиобщественному поведению;

- компрометация государственных институтов, провоцирование кризиса доверия к политическому руководству и лично к президенту республики А.Г. Лукашенко;

- склонение масс к протестным, в т.ч. несанкционированным, акциям, представляемым как адекватная реакция на «антинародные» действия правоохранительных органов;

- вытеснение из информационного пространства страны продукции государственных национально ориентированных информационно-коммуникационных ресурсов, формирующих патриотическое общественное мнение и самоидентификацию белорусского народа;

- формирование протестных сетевых сообществ и привлечение отдельных блогеров для распространения сознательно искаженной или ложной информации, выдвижение и популяризация оппозиционных лидеров, создание альтернативных «демократических» общественных органов власти, состоящих из представителей непримиримой оппозиции;

- отвлечение внимания общественности на второстепенные социальнополитические темы, выгодные для организаторов осуществляемой «цветной революции».

История «цветных революций» во всех охваченных ими странах свидетельствует, что высшую ступень в иерархии субъектов, осуществлявших их внешнеполитическое информационно-идеологическое обеспечение, всегда занимала созданная в США и странах ЕС сеть специализированных государственных институтов и общественных объединений. В их задачу входит поиск и сбор подходящей для тенденциозной интерпретации информации, ее аналитическая и смысловая обработка, подготовка базового материала для трансляции на целевые аудитории атакуемых стран и передача его оппозиционным структурам 
и лицам для распространения в электронном виде и на бумажных носителях. Такие структуры оперативно реагируют на складывающуюся социально-политическую конъюнктуру, молниеносно наполняя мировое информационное пространство выгодными Западу материалами против государства, намеченного в качестве жертвы внешней экспансии.

Точно такая же аналогия просматривается в Беларуси, в отношении которой применяемый информационно-психологический инструментарий «цветных революций» был расширен за счет других средств, которые вряд ли можно отнести к категории «мягких».

Об этом 29 сентября недвусмысленно заявил директор Службы внешней разведки РФ С.Е. Нарышкин. По его словам, США «сыграли ключевую роль в подготовке антиправительственных протестов в Белоруссии. Хотя в публичном пространстве Вашингтон пытается держаться в тени». По утверждению C.Е. Нарышкина, «США в 2019 году и начале 2020 года по линии НПО (неправительственных организаций) направили на организацию антиправительственных выступлений порядка 20 млн. долларов. 〈...> На эти средства осуществлялось формирование сети "независимых блогеров" и информационных аккаунтов в соцсетях, подготовка активистов к проведению уличных акций. Наиболее перспективные из них проходили обучение за рубежом, в частности в Польше, Литве и на Украине, где с ними занимались опытные американские инструкторы» ${ }^{1}$. Всего же за период с 2008 по 2019 г. на финансирование программ «демократизации» республики западными странами потрачено 128 млн долл. ${ }^{2}$

Весьма весомый вклад в формирование и разжигание протестных настроений в белорусском обществе внесли прозападные местные НКО, финансируемые через цепочку посредников американским агентством USAID. Среди посредников наиболее известными являются Международный республиканский институт $(I R I)$ Дж. Маккейна, фонд «Евразия» $(E F)$ бывшего советника Е. Гайдара А. Аслунда, институт «Открытое сообщество» Дж. Сороса. Их сотрудничество с белорусскими реципиентами строится практически полностью по аналогичной с украинской «домайданной» схеме воздействия на общественные настроения.

Поскольку прозападные НКО лишены возможности проводить широкую работу на территории Беларуси, а многие из них запрещены органами власти, ряд организаций базируются в Литве. Среди них наиболее заметную роль играет Европейский гуманитарный университет, занимающийся подготовкой новых кадров для белорусской оппозиции. Однако некоторые прозападные аналитические центры, например фонд им. Л. Сапеги, Belarus Security Blog (BSBlog), a также Центр стратегических и внешнеполитических исследований продолжают действовать на белорусской территории.

К белорусским НКО, специализирующимся преимущественно на информационной деятельности, относятся интернет-портал белорусской оппозиции «Хартия-97», газеты «Народная воля» и «Белорусский партизан», радиостанции «Радио Свобода» и «Радые Рацыя», а также телеканал Belsat TV, имеющие смешанное польско-американское финансирование ${ }^{3}$.

Эффективность западных и прозападных НКО в Беларуси считается относительно невысокой. Но реальное влияние тиражируемых ими оппозиционных настроений нельзя недооценивать. Так, замечено, что де-факто оно отражается и на политических установках правящих белорусских кругов, которые перио-

\footnotetext{
${ }^{1}$ Глава СВР обвинил США в подготовке протестов в Белоруссии. Доступ: https://tass.ru/ politika/9471673 (проверено 02.03.2021).

2 https://jamestown.org/program/the-growing-importance-of-belarus-on-natos-baltic-flank/

3 Доклад в Совете Безопасности Российской Федерации в ноябре 2019 года.
} 
дически перехватывают лозунги своих политических оппонентов по «национальному вопросу» и российско-белорусским отношениям ${ }^{1}$.

К своеобразным субъектам, ратовавшим за «цветную революцию» в Беларуси, относятся также «путешествующие по стране Евросоюза белорусские политические мигранты», на которых обратил внимание министр иностранных дел РФ С.В. Лавров, подчеркнувший, что они «нацелены не на поиск диалога, а на выдвижение ультиматумов» и «на раскручивание конфликта» 2 .

Кроме того, к категории субъектов организации и осуществления информационной агрессии в отношении Беларуси следует причислить диссидентствующие белорусские сетевые сообщества, часть которых была создана заблаговременно и находилась до часа «X» в «консервации»; протестные группы из числа жителей страны, внедренные в национальные социальные сети и местную блогосферу; ангажированные некоммерческие организации и фонды, финансируемые из-за рубежа; зарубежные и национальные «независимые» массмедиа; редакции белорусских оппозиционных интернет-сайтов в Польше и Чехии; заграничные «свободные» радиостанции, прежде всего Си-Эн-Эн (США) и Би-Би-Си (Великобритания), а также белорусская редакция «Радио Свобода», расположенная в Праге, где оппозиционеры из Беларуси находят источник доходов, площадку для самоорганизации, возможность для собственной презентации и ретрансляции своих взглядов ${ }^{3}$.

Весьма широк диапазон белорусских объектов информационно-психологического воздействия. Наиболее уязвимым звеном для обработки и склонения к протестным акциям являлась молодежь в силу недостаточного жизненного опыта, неустойчивого мировоззрения, природной мобильности, податливости к быстрым, внешне эффектным радикальным решениям. Особо привлекательную аудиторию представляли студенты вузов, среди которых выделялись обучающиеся за рубежом, прибывшие, как по команде, на родину к началу протестных выступлений.

В качестве восприимчивых объектов агитации, потенциально способных подключиться к участию в акциях неповиновения и противоправного поведения, рассматривались представители творческой интеллигенции, деятели искусства и литературы, которые не нашли признания в своей стране, чаще всего в силу собственной несостоятельности, и поэтому недовольные, поскольку считают, что их недооценивает и незаслуженно ущемляет «тоталитарный» режим.

К контингенту, на который было направлено повышенное внимание в пропагандистско-агитационной работе, относились также научные и экспертные сообщества, лидеры молодежных организаций, неправительственные объединения, сотрудники IT-компаний, а также прослойки местного населения, в той или иной степени недовольные властью по самым разным причинам ${ }^{4}$.

Определенной новацией можно считать попытки лишения правящих кругов Беларуси политической опоры путем склонения на сторону протестующих парламентариев, работников государственных органов управления различных

\footnotetext{
1 Там же.

2 Лавров: призывы путешествующих по ЕС белорусских политмигрантов нацелены на раскручивание конфликта. Доступ: https://www.belta.by/politics/view/lavrov-prizyvyputeshestvujuschih-po-es-belorusskih-politmigrantov-natseleny-na-raskruchivanie-418183-2020/ (проверено 02.03.2021).

3 Какую роль сыграла Чехия в акциях против Лукашенко. Доступ: https://www.rubaltic. $\mathrm{ru} /$ article/politika-i-obshchestvo/20200813-kakuyu-rol-sygrala-chekhiya-v-aktsiyakh-protivlukashenko/ (проверено 02.03.2021).

4 Протесты в Белоруссии: уроки для России. Доступ: https://octagon.media/politika/ protesty_v_belorussii_uroki_dlya_rossii.html (проверено 02.03.2021).
} 
уровней и сотрудников силовых структур. В отношении последних эффект усиливался посредством напоминания о незавидной судьбе офицеров украинского «Беркута», а для выведения сотрудников из равновесия и запугивания в Интернете выкладывались их персональные данные ${ }^{1}$.

Включение в орбиту информационной обработки военнослужащих и сотрудников правоохранительных органов отметил министр иностранных дел РФ С.В. Лавров, сообщивший, что оппозиция призывала их «нарушать присягу, уйти “в подполье”, перейти на сторону радикальной оппозиции» 2 .

Среди исполнителей насильственных акций в ходе протестных выступлений выделялись уже упоминавшиеся студенты, число которых в зарубежных университетах весьма внушительно. Так, за последние 20 лет в Чехии окончили университеты несколько тысяч белорусских студентов. Сегодня в чешских вузах за счет государственного бюджета Чехии обучаются больше тысячи студентов ${ }^{3}$. В Польше в настоящее время проходят обучение около 8 тыс. студентов из Беларуси. Их настрой нетрудно себе представить. Привлекает молодых людей в эту страну признание польских дипломов о высшем образовании в странах Европейского союза и в США 4 . Кстати, вряд ли послужит усилению патриотических настроений студентов этой категории возможная перспектива подтверждения польских дипломов у себя на родине, о чем заявил президент Белоруссии А.Г. Лукашенко 5 .

В качестве средств для осуществления «цветной революции» в Беларуси использовались неоднократно испытанные в других странах - жертвах переворотов информационные каналы сети Интернет, превращенные в платформу для организации протестов. С распространением мобильного Интернета и технологии $W i-F i$ возросло число пользователей мессенджеров для обмена сообщениями в разных форматах (текст, звуковые сигналы, видео, фотографии, графика) в реальном времени между группами оппозиционеров и всеми пользователями, которые таким образом оказывались в сфере целенаправленного воздействия соответствующей информации.

Главным рупором оппозиционного движения позиционирует себя телеграмканал NEXTA (от белорусского слова нехта - некто), созданный в 2018 г. на базе pecypca YouTube. Наиболее известной публикацией этой новостной службы стало обнародование псевдосенсационных материалов о фактах коррупции в Беларуси и демонстрация широко разрекламированного документального фильма «Лукашенко: криминальные материалы», который официальные белорусские власти квалифицировали как экстремистский. По данным украинского отделения корпорации Би-Би-Си, фильм просмотрели около 3 млн чел. ${ }^{6}$

После президентских выборов в Беларуси и начавшихся протестных выступлений NEXTA, помимо информационно-оповещательной функции, выдвинулась на роль координатора оппозиционного движения. На канале стали регулярно появляться призывы к оказанию материальной помощи протестующим, размещаться координаты дислокации милицейских подразделений в населенных пунктах республики, раскрываться персональные данные служащих МВД

\footnotetext{
1 Там же.

2 Лавров: призывы путешествующих по ЕС белорусских политмигрантов нацелены на раскручивание конфликта.

3 Какую роль сыграла Чехия в акциях против Лукашенко.

4 Лукашенко о белорусах-студентах в Польше: «Они должны будут подтвердить здесь диплом». Варшава ответила. Доступ: https://gomel.today/2020/09/25/277871/html (провереHo 02.03.2021).

5 Там же.

6 What is Belarusian Telegram Channal NEXTA. Доступ: https://jamestown.org/program
} 
(до сентября 2020 г. было опубликовано более 1 тыс. таких сообщений), излагаться инструкции по организации протестных акций, озвучиваться призывы к нападению на сотрудников милиции 1 .

В конце августа 2020 г. NEXTA обнародовала стратегию протестного движения в Беларуси с претенциозным названием «План победы». Ключевыми положениями стратегии являются «смещение с поста президента республики А.Г. Лукашенко, проведение новых президентских выборов, освобождение всех политических заключенных, привлечение к суду сотрудников спецслужб, причастных к злоупотреблению своим служебным положением при задержании протестующих в ходе манифестаций» 2 .

В течение нескольких дней августовских событий в Беларуси популярность телеграм-канала стремительно возросла, и к сентябрю число его подписчиков достигло 2,5 млн, а на YouTube произошло 530 тыс. просмотров. NEXTA выпускает несколько тысяч сообщений в час и вошла в шестерку самых популярных мировых телеграм-каналов, став одновременно наиболее крупным в мире русскоязычным зарубежным телеграм-каналом ${ }^{3}$.

Основатели канала утверждают, что его деятельность финансируется исключительно за счет средств, получаемых от рекламы и пожертвований частных лиц. В действительности имеется немало подтверждений, что тайными спонсорами NEXTA являются зарубежные правозащитные и проправительственные, в первую очередь польские и литовские, организации, а также западные спецслужбы, о чем, как отмечалось, определенно заявил директор Службы внешней разведки РФ С.Е. Нарышкин ${ }^{4}$.

Вызывает также сомнение, что команда канала, состоящая якобы всего из нескольких человек под руководством блогера Степана Путило и журналиста Романа Протасевича, возраст которых едва превышает 20 лет, за пару недель смогла развернуть такую бурную финансово- и трудозатратную деятельность.

Для поддержания бесперебойной связи между организаторами и активистами протестных выступлений западные специалисты на платформе Twitter разработали функцию, позволяющую через местную мобильную сеть передавать сообщения на случай блокировки Интернета в стране. Помимо этого, были созданы «антивирусные» программы, которыми снабжались участники протестных акций, дающие возможность доносить нужную информацию до адресатов.

Для обеспечения безопасности протестующих применялись особые мобильные технологии, позволяющие нажатием одной кнопки предупреждать единомышленников об опасности [Антюхова 2015].

Среди наиболее характерных методов давления на власти страны выделялись манифестации, протестные митинги и демонстрации, блокировка дорог, срыв железнодорожного сообщения, попытки организации забастовок рабочих крупных промышленных предприятий, агрессивное сопротивление правоохранительным органам, попытки захвата административных учреждений, провокации различной остроты и направленности. Основным девизом протестов стал лозунг: «бросать вызов власти и отказываться от повиновения». Не был забыт и популярный элемент всех «цветных революций» - назначение «сакральной жертвы» режима. Как обычно в таких случаях, сценарий действа был детально продуман: посещение демонстрантами места смерти погибшего во время массовых беспорядков в Минске Александра Тарайковского, возложение цветов

1 https://t.me/nexta_tv/3851

$2 \mathrm{https} / / /$ t.me/nexta_tv/3852

3 Telegram Analytics. Доступ: tdstat.com (проверено 02.03.2021).

4 Глава СВР обвинил США в подготовке протестов в Белоруссии. Доступ: https://tass.ru/ politika/9471673 (проверено 02.03.2021). 
на этом месте послами некоторых европейских стран, аплодисменты присутствующих по этому поводу и крики: «спасибо». В соцсетях распространялись призывы к неравнодушным гражданам прийти проститься с «героем», а по всей Беларуси предлагалось почтить память погибшего минутой молчания ${ }^{1}$.

Следует выделить неудавшиеся попытки оппозиционеров совершить террористические акты в общественных местах ${ }^{2}$ и радикализировать протестные выступления посредством их подчинения местным националистам и русофобам, копировавшим действия украинских националистов. В рядах их последователей появился заимствованный на Украине и приспособленный к местным условиям лозунг: «Живе Белорусь!»

Вполне предсказуемой была реакция ведущих стран Европы и США на события, происходящие в Беларуси. В этом отношении сработал ставший привычным для них синдром двойных стандартов: резкое осуждение мер белорусского правительства по поддержанию конституционного порядка и законности в своей стране, выставляемых как свидетельство диктатуры и деспотизма, и жесткое подавление протестных акций в собственных государствах, которое преподносится как объективная необходимость защиты демократии от разбушевавшихся маргиналов и хулиганов.

С целью усиления воздействия на А.Г. Лукашенко Запад не отказывался от прямых угроз отключения страны от международной системы взаимных расчетов во внешней торговле $S W I F T$, если президент не покинет свой пост, что равноценно откровенному шантажу. Не иначе как шантаж следует расценивать также призыв Комитета Европарламента приостановить предстоящий в ближайшее время запуск в эксплуатацию геополитического проекта Российской Федерации и Беларуси - БелАЭС под надуманным предлогом несоответствия международным стандартам природоохранной и ядерной безопасности ${ }^{3}$.

Финансирование информационно-коммуникационной поддержки запланированного государственного переворота осуществлялось преимущественно из-за рубежа через существующие или специально созданные с этой целью фонды «сочувствующими» иностранными спонсорами, в т.ч. такими одиозными личностями, как Сорос. В ряде случаев использовались известные легальные общественные организации, которые легендировали направление финансовых средств физическим и юридическим лицам в Беларуси гонорарами за литературные произведения, грантами за научные и публицистические труды, реализацией образовательных проектов и помощью бизнесу. Значительные суммы направлялись в национальные оппозиционно настроенные НКО, «независимые» СМИ либо передавались непосредственно активистам сотрудниками иностранных дипломатических миссий. Как правило, такая конспиративная функция возлагалась на оперативный состав резидентур иностранных государств, действующих под прикрытием дипломатических представительств в Беларуси.

Информационное обеспечение участников организации и осуществления «цветной революции» составляло важную часть подрывной идеологической работы их инициаторов. Ее суть сводилась к подготовке тенденциозно обработанных информационных материалов и их распространению в сети Интернет, а также в бумажном варианте среди активистов организации протестов. Помимо соответствующей информационной подпитки исполнителей антиобщественных акций, информационное обеспечение предусматривало распространение

1 Протесты в Белоруссии: уроки для России.

2 Парламентское собрание Союза Беларуси и России. Управление по связям с общественностью и взаимодействию со СМИ. Публикации по белорусско-российской тематике в средствах массовой информации. 29 января 2021 года.

3 Там же. 
подробных инструкций, излагавших приемы мобилизации людей на демонстрации и управления массами во время протестов, эффективные способы противодействия правоохранительным органам, а также методы борьбы с режимом в целом.

И наконец, важную роль играла активная политическая, правовая и морально-психологическая поддержка из-за рубежа протестного движения в Беларуси и участников противоправного поведения, задержанных и привлеченных к административной или уголовной ответственности по решению суда. Подбор и оплата квалифицированных адвокатов для их защиты в ходе судебных разбирательств и подача кассационных жалоб соответствовали отработанной инициаторами «цветных революций» практике так же, как и демонстративные ходатайства руководителей отдельных иностранных государств об освобождении задержанных и осужденных за участие в массовых беспорядках.

Тем не менее главный упор в поддержке Западом белорусского протестного движения делался на оказании политического, экономического, идеологического и психологического давления на руководство республики с целью принуждения к выполнению требований оппозиции. К этому процессу были подключены все подконтрольные западному миру силы в лице ряда международных структур, коалиций государств, парламентов отдельных стран и высокопоставленных чиновников.

Так, в октябре 2020 г. Совет Европейского союза принял Декларацию (Conclusion) по вопросу о положении в Беларуси. В документе в жестких тонах дается оценка прошедших в стране президентских выборов, в ультимативной форме высказывается требование к властям республики «незамедлительно провести новые, свободные и честные выборы», сообщается о принятии пакета санкций в отношении лиц, которые, по мнению Совета Европейского союза, «ответственны за мошеннический характер президентских выборов и жесткое подавление мирных протестов». Европейский союз выразил готовность «предпринять дополнительные репрессивные меры, в том числе против высокопоставленных официальных лиц Белоруссии, включая президента Лукашенко». Одновременно анонсируется намерение «активизировать взаимодействие с ключевыми неправительственными белорусскими бизнес-структурами» ${ }^{1}$.

В Декларации подчеркивается, что «Европейский союз незамедлительно выделит дополнительные финансовые ресурсы для жертв насилия, неправительственных местных и региональных сообществ, а также для гражданских общественных организаций и независимых СМИ» 2 .

В октябре 2020 г. свое официальное отношение к событиям в Беларуси высказало руководство НАТО. На официальном интернет-сайте Альянса было опубликовано заявление об основах отношений с Беларусью в свете происходящих там событий после президентских выборов. В документе говорится о стремлении руководства НАТО продолжать сотрудничество с Беларусью в соответствии с положениями Совета Евроатлантического партнерства, в который Беларусь вошла в 1992 г., и одновременно реализация этого намерения ставится в зависимость от «прогресса в проведении демократических реформ».

В заявлении содержится обращение к неправительственным и общественным организациям республики «активнее участвовать в мероприятиях, проводимых отделом общественной дипломатии NATO» ${ }^{3}$.

О намерении Альянса продолжить свою деятельность в белорусском направ-

1 Brussels, 13/10/2020 - 09:39, UNIQUE ID: 201013_2.

2 Ibid.

3 Relations with Belarus. URL: https://www.nato.int/cps/en/natohq/topics_49119.htm (accessed 02.03.2021). 
лении в прежнем деструктивном ключе свидетельствует доклад Атлантического совета НАТО от 27 января 2021 г., в который включены рекомендации для администрации Джо Байдена «сохранить ставку на дестабилизацию экономики Белоруссии, оказывать поддержку оппозиционному лидеру Тихановской, ежегодно выделять “гражданскому обществу” страны 200 млн долларов»1.

Повышенное внимание Североатлантического блока к Беларуси вызывается, как это отмечают ряд западных политологов и военных экспертов, особым отношением к этой стране как к «стратегическому буферу между Россией и странами Балтии, входящими в НАТО» и «бастиону против российского империализма» ${ }^{2}$. Одновременно не скрывается, что ценность Беларуси для Альянса заключается в том, что эта страна «свободна от сухопутных войск России и новых российских авиабаз, из-за которых пришлось бы серьезно сократить время готовности и предупреждения для вооруженных сил НАТО, развернутых на Балтике». Руководство НАТО исходит из того, что «заключение Беларусью де-юре военного союза с Россией не столь важно, поскольку республика служит интересам НАТО, оставаясь де-факто нейтральным и неприсоединившимся государством». По этой причине «НАТО необходимо активизировать связи с Беларусью» ${ }^{3}$.

Фактически сразу после начала протестных выступлений в Беларуси (11 августа 2020 г.) министры иностранных дел Люблинского треугольника, включающего Литву, Польшу и Украину, в коллективном заявлении призвали белорусские власти «воздержаться от применения силы и освободить всех задержанных» ${ }^{4}$.

С аналогичным призывом в заявлении о «крупномасштабных фальсификациях в ходе выборов» 12 августа выступили министры иностранных дел многостороннего диалогового формата Nordic-Baltic Eight - «северобалтийской восьмерки» (Дания, Исландия, Латвия, Литва, Норвегия, Финляндия, Швеция, Эстония $)^{5}$.

Президенты Литвы, Латвии, Польши и Эстонии 13 августа также опубликовали совместное заявление, в котором призвали к «немедленной деэскалации ситуации и прекращению применения силы против народа, ...освобождению всех участников протестов и прекращению их преследования, ...началу диалога с гражданами Беларуси» путем «организации круглого стола по национальному примирению с участием представителей правительства и гражданского общества», а также предложили «свои посреднические услуги для достижения мирного урегулирования в Беларуси и укрепления ее независимости и суверенитета» 6 .

Премьер-министры Прибалтийских государств 15 августа в ходе встречи в Тарту, в свою очередь, предложили провести «прозрачные, свободные и спра-

\footnotetext{
1 Парламентское собрание Союза Беларуси и России. Управление по связям с общественностью и взаимодействию со СМИ. Публикации по белорусско-российской тематике в средствах массовой информации. 29 января 2021 года.

2 https://jamestown.org/program/the-growing-importance-of-belarus-on-natos-baltic-flank/

3 Ibid.

4 Lietuvos, Lenkijos ir Ukrainos („Liublino trikampio“) užsienio reikalų ministrų pareiškimas. 2020.08.11. Доступ: http://urm.lt/default/lt/naujienos/lietuvos-lenkijos-ir-ukrainos-liublinotrikampio-uzsienio-reikalu-ministru-pareiskimas (проверено 02.03.2021).

5 Bendras Šiaurès ir Baltijos šaliu užsienio reikalu ministru pareiškimas dèl pastaruju ìvykiu Baltarusijoje. 2020.08.12. Доступ: http://urm.lt/default/lt/naujienos/bendras-siaures-ir-baltijossaliu-uzsienio-reikalu-ministru-pareiskimas-del-pastaruju-ivykiu-baltarusijoje (проверено 02.03.2021).

6 Lietuvos, Lenkijos, Latvijos ir Estijos Prezidentu raginimas imtis veiksmų dėl Baltarusijos. 2020.08.13.Доступ:https://www.lrp.lt/lt/lietuvos-lenkijos-latvijos-ir-estijos-prezidenturaginimasimtis-veiksmu-del-baltarusijos/34520 (проверено 02.03.2021).
} 
ведливые президентские выборы при участии международных наблюдателей» 1 и выразили готовность «ввести индивидуальные санкции ЕС в отношении представителей власти Беларуси, несущих непосредственную ответственность за подавление протестов»².

Сейм Литовской Республики 18 августа принял резолюцию «О положении в Республике Беларусь после сфальсифицированных выборов Президента», в которой обратился к лидерам Литвы, Совета ЕС, Европейской комиссии, Европейского парламента, а также к национальным парламентам и правительствам ЕС и НАТО с призывом «не признавать результаты выборов в Беларуси, а Александра Лукашенко - законным главой Беларуси, провести новые президентские и парламентские выборы, освободить всех заключенных представителей оппозиции и гражданского общества, незамедлительно создать посредническую миссию ЕС в Беларуси, ввести индивидуальные санкции в отношении белорусских чиновников, поощрять активную поддержку и оказание непосредственной помощи белорусским неправительственным организациям и сообществам» 3 .

Руководствуясь этой резолюцией, 10 сентября сейм Литвы принял новую резолюцию «О нелегитимном союзе с Россией, навязанном Беларуси», в которой призвал международное сообщество «поддержать требования избранной белорусским народом лидера Светланы Тихановской и созданного по ее инициативе Координационного совета признать их единственными легитимными представителями белорусской нации... оценивать любые действия нелегитимного главы Беларуси А. Лукашенко как преступление против своего народа, соответственно, ничтожные и не признанные международным сообществом - de facto аннексию страны»; «добиваться от России не вмешиваться во внутреннюю и внешнюю политику Беларуси» ${ }^{4}$.

Почти сразу же с начала белорусских событий некоторые европейские высокопоставленные чиновники перешли на язык угроз А.Г. Лукашенко. Так, глава МИДа Чехии Томаш Петршичек в беседе с журналистами заявил о «возможности финансового влияния на Минск через организацию Восточное партнерство, членом которой является Беларусь» 5 . Свою мысль министр продолжил, заявив, что «может встать вопрос о том, надо ли в такой ситуации финансировать некоторые проекты в Беларуси» 6 . Такое поведение Петршичека не случайно. В результате проводимой в последние 20 лет внешней политики Прага превратилась в третий центр белорусской оппозиции после Вильнюса и Варшавы ${ }^{7}$.

\footnotetext{
1 Премьеры стран Балтии призывают провести новые президентские выборы в Беларуси. 15.08.2020. Доступ: https://lv.sputniknews.ru/Baltics/20200815/14212433/Premery-stran-Baltiiprizyvayut-provesti-novye-prezidentskie-vybory-v-Belarusi.html (проверено 02.03.2021).

2 L. Linkevičius: būtinos ES sankcijos už smurta ir suklastotus rinkimus atsakingiems Baltarusijos pareigūnams. 2020.08.14. Доступ: http://urm.lt/default/lt/naujienos/l-linkevicius-butinos-essankcijos-uz-smurta-ir-suklastotus-rinkimus-atsakingiems-baltarusijos-pareigunams (проверено 02.03.2021).

3 Rezoliucija dèl padèties Baltarusijos Respublikoje po suklastotu Prezidento rinkimu. $2020 \mathrm{~m}$. rugpjūčio 18 d. Nr. XIII-3281. Vilnius. Доступ: https://e-seimas.lrs.lt/portal/legalAct/lt/TAD/ec6 e5f20e1e811ea85df91a432b58c48?jfwid=-1 txwxfiwp (проверено 02.03.2021).

4 Rezoliucija dèl neteisètos ir primetamos Rusijos sajungos Baltarusijai. $2020 \mathrm{~m}$. rugsėjo $10 \mathrm{~d}$. Nr. XIII-3282. Vilnius. Доступ: https://e-seimas.lrs.lt/portal/legalAct/lt/TAP/7d1d07b1f28811ea b72ddb4a109da1b5 (проверено 02.03.2021).

5 Организация «Восточное партнерство» основана в 2009 г. как проект Европейского союза. Ее членами, помимо Беларуси, являются Азербайджан, Армения, Грузия, Молдова и Украина. Официально провозглашенной целью организации является углубление и укрепление отношений ЕС с шестью восточными странами бывшего СССР в форме реализации инфраструктурных и межрегиональных проектов.

6 file://C:/Users/user/Downloads/1575715337.html

7 Какую роль сыграла Чехия в акциях против Лукашенко.
} 
Нескрываемая заинтересованность Чехии в реализации «цветной революции» в Беларуси объясняется, помимо европейской солидарности, экономическими причинами, в частности, стремлением расширить собственный сегмент рынка в Беларуси; реальной вероятностью банкротства большинства белорусских крупных промышленных предприятий в случае успеха «цветной революции», что сильно ослабит Беларусь как экономического конкурента на мировом рынке; а также перспективой переманивания белорусских высококвалифицированных кадров в случае удавшегося государственного переворота в Беларуси 1 .

По всей вероятности, было бы односторонним рассматривать все многообразие сложных событий белорусского кризиса через призму преимущественно внешних факторов. Следует признать, что во внутренней жизни страны также имелись основания политического и социально-экономического характера, способствовавшие, по мере накопления, обострению обстановки и проявлению недовольства определенной части населения, которое было подхвачено, раскручено и использовано недоброжелателями Беларуси.

Очевидно и то, что декларированная руководством республики «многовекторность» внешней политики, на которую в последние годы была сделана ставка, привела к известному дистанцированию Беларуси от Российской Федерации и дрейфу в сторону Запада. Во внутренней белорусской пропаганде стал популяризироваться мотив евроинтеграции, усилилась поддержка молодежных НКО независимо от их политической ориентации, расширились возможности для студентов выезжать на учебу в университеты Польши, Литвы и других стран Евросоюза.

Страны ЕС и США приветствовали нежелание А.Г. Лукашенко признать Крым территорией России, его контакты с президентом Украины Владимиром Зеленским, отказ Минска разместить на территории страны российскую военную базу. Подключены также финансовые и экономические рычаги воздействия на Беларусь в желательном для Запада направлении: в рамках работающих программ в 2014-2018 гг. из бюджета ЕС республике выделено около 131,2 млн долл. ${ }^{2}$, для формирования институциональной основы в экономической сфере учрежден торговый диалог «Беларусь - ЕС», который призван наладить систему обмена информацией по вопросам регулирования торговых отношений, исходя из того, что ЕС является вторым торговым партнером Беларуси (после России) с долей около $30 \%$ совокупной внешней торговли республики ${ }^{3}$.

За 27 лет правления президента А.Г. Лукашенко в Беларуси произошла смена поколений, изменился состав общества: увеличилось число людей, работающих в частных структурах и в IT-отрасли, ориентирующихся на горизонтально организованную информационную сетевую культуру, потеснившую традиционную систему коммуникаций государственного политического режима с обществом ${ }^{4}$. Минск ввел безвизовый режим для граждан 80 стран, включая США и большинство их союзников по НАТО и ЕС. При этом заверения белорусских властей о недопуске на территорию республики нежелательных для России лиц остаются нереализованными.

Не может не вызывать обеспокоенность усиление националистических тенденций среди белорусской интеллигенции, и это увеличивает духовно-культур-

\footnotetext{
1 Там же.

2 Материалы к заседанию секции по проблемам СНГ научного совета при Совете безопасности $\mathrm{PФ} \mathrm{«О} \mathrm{перспективах} \mathrm{развития} \mathrm{российско-белорусского} \mathrm{сотрудничества} \mathrm{и} \mathrm{мерах}$ по углублению союзной интеграции», ноябрь 2019 года.

3 Там же.

4 Карбалевич В. Пассионарный взрыв. Доступ: https://www.sn-plus.com/2021/01/05/ passionarnyj-vzryv/ (проверено 02.03.2021).
} 
ную дистанцию между народами России и Беларуси. В республиканских СМИ широко представлены материалы, ориентированные на отрыв от общерусской идентичности и замену ее белорусской, на искажение исторической памяти белорусских граждан ${ }^{1}$.

Все это постепенно привело к формированию соответствующей атмосферы в белорусском обществе, создало предпосылки для критического осмысления распространенных стандартных установок о месте Беларуси среди славянских народов и стало благодатной почвой для восприятия «авангардных» идей европейских цивилизованных стран, которые (идеи) подталкивали «мыслящих людей» к «демократическим преобразованиям» по ими же идеализированному образцу.

Как показала практика, властям Беларуси не удалось вовремя обнаружить растущую трансформацию настроений значительной части населения страны, особенно молодежи, и формирование немалой по численности социальной базы протестных выступлений, чтобы своевременно и эффективно реагировать на развивающиеся события, купировать неблагоприятные тенденции.

Сформировавшаяся вертикаль власти, практически полностью сосредоточенная в руках президента страны и, по сути, размытая в регионах и муниципалитетах, не имевших четко определенных полномочий на случай острых нештатных ситуаций, оказалась не в состоянии действовать самостоятельно, быстро, последовательно и согласованно. По этой же причине руководители государственных промышленных предприятий, непосредственно столкнувшиеся с назревающей опасностью провоцируемых извне забастовок работников, проявили растерянность и не сразу смогли принять меры к их недопущению и блокировке там, где они обозначились. На всех этажах государственного управления ощущалось несовершенство правовой базы, необходимой для эффективного противодействия вероятным и вполне предсказуемым вызовам и угрозам «цветных революций».

Сказалась также избыточная вера правящих кругов в самодостаточность репрессивных мер для подавления протестов, которые, как предполагалось, можно произвольно наращивать в зависимости от ситуации. На деле же оказалось, что жесткое применение силы к демонстрантам, характерное для первого этапа противодействия волнениям, дало обратный эффект - привело к увеличению числа возмущенных граждан, недовольных еще и задержанием журналистов и случайно оказавшихся на месте манифестаций жителей.

Приходится также констатировать, что национальные информационно-коммуникационные ресурсы и патриотически настроенные СМИ слабо освещали поведение и настроения сторонников действующего президента страны и поддержку с их стороны законности его избрания на новый срок полномочий. В то же время все национальное новостное поле было заполнено негативной информацией и повторяющимися критическими сюжетами, играющими на руку протестующим.

Подводя итог изложенному, можно предположить долговременный характер массированного давления Запада на Беларусь в связи с ее геополитическим значением и восточноевропейским стратегическим расположением. Имеется немало подтверждений намерений противников Беларуси сохранить всеобъемлющий международный политический, экономический и психологический прессинг страны, продолжить линию на ее международную изоляцию. При этом на Западе происходит серьезное осмысление способов повышения эффек-

1 Доклад в Совете Безопасности Российской Федерации в ноябре 2019 года. 
тивности принимаемых в отношении Беларуси мер и критическая оценка собственного поведения.

На фоне ослабления «пояса безопасности» по периметру границ России, особенно с учетом обстановки на Украине, неблагоприятные перспективы развития белорусского политического кризиса, вполне возможные при сохранении протестного потенциала в республике, могут иметь для России не только региональное, но и глобальное значение.

Беларусь как суверенный субъект международного права, союзное нашей стране государство и западный совместный оборонительный форпост подвергается беспрецедентному испытанию на прочность. И от того, выдержит ли страна испытание, во многом зависит будущее не только наших межгосударственных отношений, но, в известной мере, судьба дальнейшего развития Организации Договора о коллективной безопасности (ОДКБ), Евразийского экономического союза (ЕАЭС), да и постсоветского пространства в целом.

Эхо белорусских событий уже сейчас резонирует в России, проявляя очевидные параллели с происходящими протестными акциями в ряде городов страны, которые были особенно активными в январе-феврале текущего года. Вдохновители протестов используют порой ничтожные поводы для их инициирования, демонстрируя знакомый почерк апробированного на «белорусском полигоне» противоправного поведения некорректно привлеченных к участию в «мероприятиях» российских граждан, в т.ч. несовершеннолетних. В этой связи для России становится чрезвычайно актуальным и важным для сохранения стабильности в обществе и поддержания на должном уровне конституционного правопорядка в стране извлечь уроки из переживаемых нашим союзником потрясений, успехов и неудач их локализации.

\section{Список литературы}

Антюхова Е.А. 2015. Технологии ведения США и НАТО информационносетевых операций в конфликтах «арабской весны». - Вестник Брянского государственного университета. № 1. С. 95-100.

GRIBIN Nikolai Petrovich, Dr.Sci. (Legal), Professor of the Moscow State Institute of International Relations, University of the Ministry for Foreign Affairs of Russia (76 Vernadskogo Ave, Moscow, Russia,119454; n.gordin40@gmail.com)

PLETNYOV Valery Yakovlevich, Cand.Sci. (Legal), Professor; Consultant of the Military Academy, Moscow; retired colonel

\section{THE «BELARUSIAN SYNDROME» IN THE CONTEXT OF THE UPDATED ROADMAP OF COLOR REVOLUTIONS}

\footnotetext{
Abstract. The article analyzes the political crisis in Belarus after the declaration of the victory of A.G. Lukashenko at the presidential elections on August 9, 2020. The authors reveal internal and external reasons and motives for protest movement of the substantial part of population. They throw light upon the mechanism of inspiring and supporting an attempted coup d'etat in the republic. Some prognoses of political trends in the country also are the part of the article.

Keywords: soft power, tools for colored revolutions, external factors, political technologies, information and communication resources, objects of influence, protest actions, anti-social behavior, opposition forces, national security of Russian Federation
} 